\title{
The first microfossil record of ichthyofauna from the Naujoji Akmenè Formation (Lopingian), Karpènai Quarry, northern Lithuania
}

\author{
Darja DANKINA ${ }^{1, *}$, Artur CHAHUD², Sigitas RADZEVIČIUS ${ }^{1}$ and Andrej SPIRIDONOV ${ }^{1}$ \\ 1 Vilnius University, Department of Geology and Mineralogy, M.K. Čiurlionio 21/27, 03101, Vilnius, Lithuania \\ 2 Instituto de Geociências, Departamento de Geologia Sedimentar e Ambiental. - USP. R. do Lago 562, CEP 05508-080, \\ Sao Paulo, Brazil
}

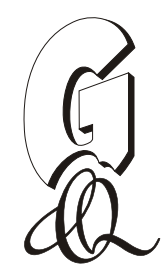

Dankina, D., Chahud, A., Radzevičius, S., Spiridonov, A., 2017. The first microfossil record of ichthyofauna from the Naujoji Akmenè Formation (Lopingian), Karpènai Quarry, northern Lithuania. Geological Quarterly, 61 (3): 602-610, doi: 10.7306/gq. 1371

\begin{abstract}
The assemblage of rare fish microremains of chondrichthyans and actinopterygians from Upper Permian deposits in Karpènai Quarry in northern Lithuania is described in detail for the first time. The deposits are characterized as reflecting a rapid phase of deposition of the Zechstein Limestone, interpreted as on a shallow shelf above storm-wave base in a proximal part of the Polish-Lithuanian Zechstein Basin. The actinopterygian microremains are represented by various teeth and a few scales from mostly palaeonisciforms and pycnodontiforms. The chondrichthyans are represented by various euselachian-type scales and a tooth of ? Helodus sp. The low abundance and low species diversity of the fossil assemblages studied may be due to arid palaeoenvironments that caused locally restricted conditions at this palaeogeographical location.
\end{abstract}

Key words: chondrichthyans, actinopterygians, Upper Permian, Zechstein Basin, northern Lithuania.

\section{INTRODUCTION}

Late Permian chondrichthyans and actinopterygians are known from Australia (Campbell and Phuoc, 1983), South Africa (Bender, 1999, 2001, 2006), China (Wang et al., 2009), Iran (Hampe et al., 2012), Greece (Argyriou et al., 2017), Russia (Minikh, 1990; Esin, 1993, 1995), and Germany (Heintz, 1934; Diedrich, 2009).

Until now only two discoveries of fish microremains have been reported from the Upper Permian of northern Lithuania. These comprise findings of a few problematic scales, interpreted as Palaeoniscus sp. (Suveizdis, 1963: pl. 13, figs. 8, 9; Suveizdis, 1975: pl. 19, fig. 5) in the Naujoji Akmenè Formation in Karpènai Quarry. One fish fossil fragment, interpreted as Platysomus sp., has also been found from the Naujoji Akmené Formation in the Žalgiriai borehole (Suveizdis, 1975: pl. 19, fig. 6). These finds were noted without detailed description or published illustration.

The present study of chondrichthyans and actinopterygians is based on isolated teeth and scales from the Naujoji Akmenè Formation of Karpènai Quarry. Palaeonisciformes (Platysomidae, Elonichthyidae, Haplolepidae families) and the Pycno-

\footnotetext{
* Corresponding author, e-mail: darja.dankina@gmail.com Received: January 25, 2017; accepted: April 28, 2017; first published online: July 28, 2017
}

dontiformes (Pycnodontidae family) actinopterygians order have been identified. The chondrichthyan microremains represent both the Holocephali and Elasmobranchii.

This study details the Upper Permian chondrichthyan and actinopterygian taxonomic and ecological records from the northeastern Zechstein Basin, which the territory of the northern Lithuania belongs to. The new data enable a better understanding of the ecosystems of the very dynamic Late Permian Lopingian Epoch (Kozur, 1995; Clapham and Bottjer, 2007).

\section{GEOLOGICAL SETTING}

Lithuania is located in the northeastern part of the Zechstein Basin (Kadunas and Raczyński, 2010; Raczyński and Biernacka, 2014) and was located some distance away from the main connection between the Arctic Boreal Ocean and the low latitude Zechstein Basin during the Late Permian (Sørensen et al., 2007; Peryt et al., 2010).

Karpenai Quarry is located in northern Lithuania near the Lithuanian/Latvian border (Fig. 1A). The Naujoji Akmenè Formation limestone (Ca1) is exposed there, and is a very important mineral resource for the cement industry in Lithuania (Gasiūnienè and Kadūnas, 1997), in which respect Karpenai Quarry has been studied (Kličius, 2006; Kličius and Čiūraitė, 2010).

The Naujoji Akmenè Formation was first distinguished by Suveizdis (1962). Three members (Figs. 1B and 2) were distinguished in the Naujoji Akmenè Formation (Paškevičius, 1997). The lower part is characterized by micritic limestone (mudstone, 


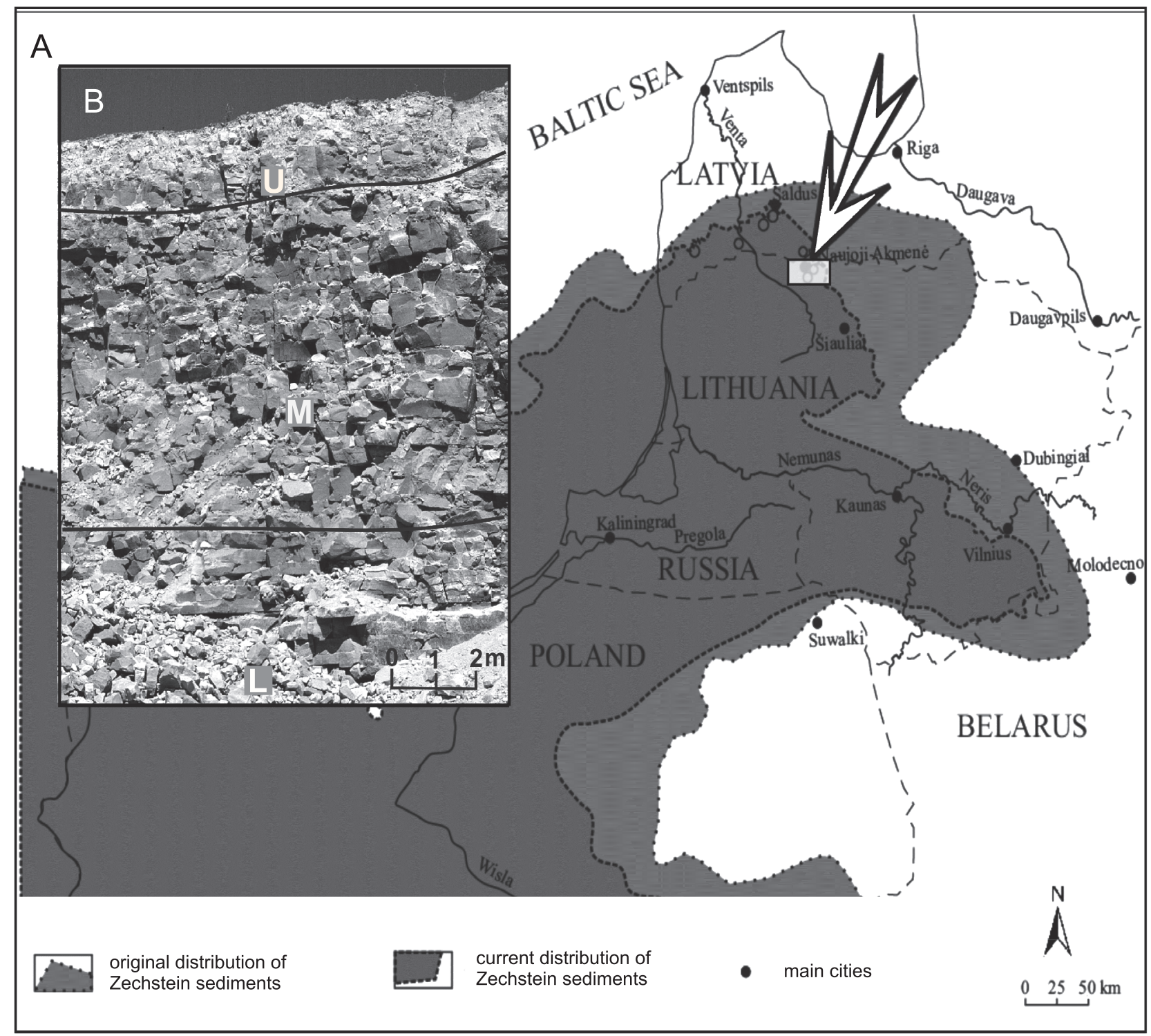

Fig. 1. Location of Karpènai Quarry

A - extent of the Zechstein Limestone in the eastern part of the Southern Permian Basin in Central Europe (after Peryt et al., 2012); B - Karpėnai Quarry stratigraphy: lower part $(L)$ - micritic limestone, middle part $(M)$ - proximal tempestites, upper part $(\mathrm{U})$ - dolomitic limestone

rarely packstone). The middle part consists predominantly of proximal tempestites (grainstone, packstone) with hard limestone concretions. The upper part is a limestone showing mudstone to grainstone texture with coated grains. Dolomitic limestone is found in the highest part of the unit.

Among the environmental changes which may have caused sea level fluctuations in the northeastern Zechstein basin (Kadūnas, 1997), humidity-aridity variations have been proposed (cf. Biernacka et al., 2005). Currently, the quarry exposes an almost complete sedimentary sequence, without the lowest part of the lower member, and the uppermost part of the upper member, of the Naujoji Akmenè Formation.

The species-rich assemblage of invertebrates consisting of foraminifers, ostracods, molluscs, brachiopods, bryozoans, and echinoderms is distributed throughout the Naujoji Akmenè Formation (Suveizdis, 1963, 1975), and faunal diversity decreases from the bottom to the top of the formation (Suveizdis, 1963).

\section{MATERIAL AND METHODS}

The new material comes from two different wall-sections ( $N$ $56^{\circ} 19.542$, E $22^{\circ} 57.219$ and N 56 19.503 , E $22^{\circ} 57.441$ using the GPS/WGS84 coordinate system) in Karpènai Quarry. The distance between these quarry walls is almost $400 \mathrm{~m}$. The height of the exploratory quarry walls is approximately $14 \mathrm{~m}$ (Fig. 1B). The samples were taken vertically every $2 \mathrm{~m}$ from the first site and every $1 \mathrm{~m}$ from the second site. As a result, 18 samples were collected from both sites. The total weight of the samples collected was $210 \mathrm{~kg}$ and samples varied from 3 to $22 \mathrm{~kg}$ (Tables 1 and 2).

All samples were dissolved with buffered $10 \%$ formic acid $\left(\mathrm{CH}_{2} \mathrm{O}_{2}\right)$ for the dolomitized deposits, and with buffered $10 \%$ acetic acid $\left(\mathrm{CH}_{3} \mathrm{COOH}\right)$ for the limestones (Jeppsson et al., 1999). The residue was naturally dried and sieved from 0.2 to $0.063 \mathrm{~mm}$ to extract the extremely tiny fish microremains and 
Some teeth have no distinct sculpture, though microtubercles are well-developed and cover the entire Karpènai exposure I

\begin{tabular}{|c|c|c|c|c|c|c|c|}
\hline \multirow[t]{2}{*}{ No. } & \multirow{2}{*}{$\begin{array}{l}\text { Height } \\
(\mathrm{m})\end{array}$} & \multirow[t]{2}{*}{ Specimen } & \multirow{2}{*}{$\begin{array}{c}\text { Weight } \\
(\mathrm{kg})\end{array}$} & \multicolumn{2}{|c|}{ Actinopterygia } & \multicolumn{2}{|c|}{ Chondrichthyar } \\
\hline & & & & Scale & Tooth & Scale & Tooth \\
\hline 1 & $12.0-14.0$ & KAR-7 & 4,4 & 0 & 1 & 1 & 0 \\
\hline 2 & $10.0-12.0$ & KAR-6 & 5,25 & 0 & 2 & 6 & 0 \\
\hline 3 & $8.0-10.0$ & KAR-5 & 3,70 & 0 & 0 & 4 & 0 \\
\hline 4 & $6.0-8.0$ & KAR-4 & 12,04 & 0 & 1 & 1 & 0 \\
\hline 5 & $4.0-6.0$ & KAR-3 & 7,86 & 0 & 9 & 7 & 0 \\
\hline 6 & $2.0-4.0$ & KAR-2 & 3,10 & 1 & 21 & 11 & 0 \\
\hline 7 & $0.0-2.0$ & KAR-1 & 9,58 & 1 & 7 & 6 & 0 \\
\hline & & Total: & 45.93 & 2 & 41 & 36 & 0 \\
\hline
\end{tabular}
preserved tooth surface. These microtubercles are narrow and vertically elongated, with oblique rows (Fig. 3G, I-K). Most scales have a rhomboidal, and in places more elongated, drop-like (Fig. 3F) shape with a poorly preserved outer surface. The surface is smooth, with no distinct ornamentation. The base is flat and thick, with no keel. These scales reach a maximum length of $1.1 \mathrm{~mm}$ and have a width of $0.6 \mathrm{~mm}$. The teeth and scales studied from Karpenai Quarry are poorly preserved. Most teeth have a distinct ornament, comparable with microsculpture of similar teeth (Štamberg, 2016). It is difficult to identify Palaeoniscus sp. based solely on the morphology of isolated scales, as there is a lack of comparative information about the scales (Esin, 1990).

Table 2 One tooth (VU-ICH-KAR-004) has been assigned to "Elonichthys" sp. (Fig. 3D). The tooth is slender and sharp-pointed in shape, with a length of $0.6 \mathrm{~mm}$, and the width of its base is $0.15 \mathrm{~mm}$. The distinct acrodin apex has a length of $0.1 \mathrm{~mm}$ (Fig. $3 D_{2}$ ). The microtubercles are well-developed. They cover the whole surface of the tooth, with the exception of the acrodin apex. The proximo-distally microtubercles are narrower, more elongated, and blend together $\left(\mathrm{Fig} .3 \mathrm{D}_{3}\right)$. The tooth has been assigned to Elonichthys based on comparison to the isolated tooth of "Elonichthys" sp. from the Black Shale Horizon of the Syřenov Formation, Upper Carboniferous in the Krkonoše Piedmont Basin (Štamberg, 2016: fig. 10A-C) which bears similar tubercles.

Two isolated teeth from the Platysomidae family (Fig. 3A, B) were found in the region under study. One tooth (VU-ICH-KAR-001) is conical and devoid of ornamentation (Fig. 3A). It reaches $1.2 \mathrm{~mm}$ in height, whereas the diameter at the base does not exceed $0.7 \mathrm{~mm}$. One crushing-type tooth (VU-ICH-KAR-002)

ease the picking process. The microremains were extracted onto microslides. A selected number of the microremains was investigated and photographed with a scanning electron microscope (SEM) at the Nature Research Centre (Vilnius, Lithuania) and at the University of Valencia (Valencia, Spain).

All the material is stored in the Geological Museum of the Institute of Geosciences Vilnius University (Lithuania).

\section{ACTINOPTERYGIAN FAUNA}

The actinopterygians are represented by their isolated teeth and scales (Tables 1 and 2) and are identified as Palaeonisciformes and Pycnodontiformes.

94 teeth and 8 scales are assigned to the Palaeonisciformes order (Fig. 3F-K) on the basis of a comparison with Palaeonisciformes-related material (Štamberg, 2016: fig. 4-6) and its description (Esin, 1990). Most of the teeth are low, not exceeding $1.2 \mathrm{~mm}$ in length, and the widths of their bases reached $0.3 \mathrm{~mm}$ (Fig. 3G-I). The teeth are conical, straight, and smooth, with acrodin caps (Fig. $3 \mathrm{H}, \mathrm{J}, \mathrm{K}$ ), or missing caps (Fig. $3 G, I)$. The distinct acrodin cap is circular in apical view, reaching a maximum diameter of $0.18 \mathrm{~mm}$, while in labial or lingual view, the acrodin cap is triangular in outline and has a length of $0.05 \mathrm{~mm}$. The corpus of these rostral teeth is sculptured, with the exception of the acrodin apex, with shallow ridges uniformly directed from the acrodin apex to the base of the tooth (Fig. $3 \mathrm{H}$ ). is oval in the occlusal-lateral view, which reaches a diameter of $0.5 \mathrm{~mm}$ in apical view and a height of $0.6 \mathrm{~mm}$ (Fig. $3 \mathrm{~B}_{1}$ ). The occlusal surface is convex (Fig. $3 \mathrm{~B}_{2}$ ). The association of conical and broad, crushing-type teeth is typical of Platysomus. There is a gradation between rounded and pointed teeth (Johnson and Zidek, 1981). Their morphology conforms with the descriptions of platysomid fish tooth plates from the upper Clyde Formation, Upper Paleozoic (Johnson and Zidek, 1981: text-fig. 3D, E).

Isolated scales (VU-ICH-KAR-005) of the Haplolepidae family (Fig. 3E) are small, reaching up to $0.8 \mathrm{~mm}$ in length and $0.6 \mathrm{~mm}$ in width. The scales are rhomboid with four sharp edges (Fig. $3 E_{1}, E_{2}$ ). A layer of ganoine tissue covers the poorly preserved outer surface. The surface has weakly pronounced sinuous parallel grooves (Fig. $3 \mathrm{E}_{1}$ ). This type of scale is probably located at the posterior part of the trunk where the fish body tapers in the caudal fin area (Trinajstic, 1977). The bases of the scales are thick and convex, with no keel. The isolated rhombic scales are assigned to the Haplolepidae family on the basis of a comparison with more complete material (Westoll, 1944). A similar rhomboidal scale from a haplolepid with a ganoine-covered outer surface and sinuous narrow grooves was found in the Rader Limestone Member of the Bell Canyon Formation, Capitanian in West Texas, USA (Ivanov et al., 2015: pl. 2, fig. 15).

Two isolated teeth from the Pycnodontidae family (Fig. 3C) were found at the site under study. The teeth (VU-ICH-KAR-003) are circular in apical view, reaching a maximum diameter of $1.2 \mathrm{~mm}$ (Fig. $3 \mathrm{C}_{3}$ ). These teeth are low, not exceeding $0.4 \mathrm{~mm}$ in height. The surface of the acrodin caps is densely 


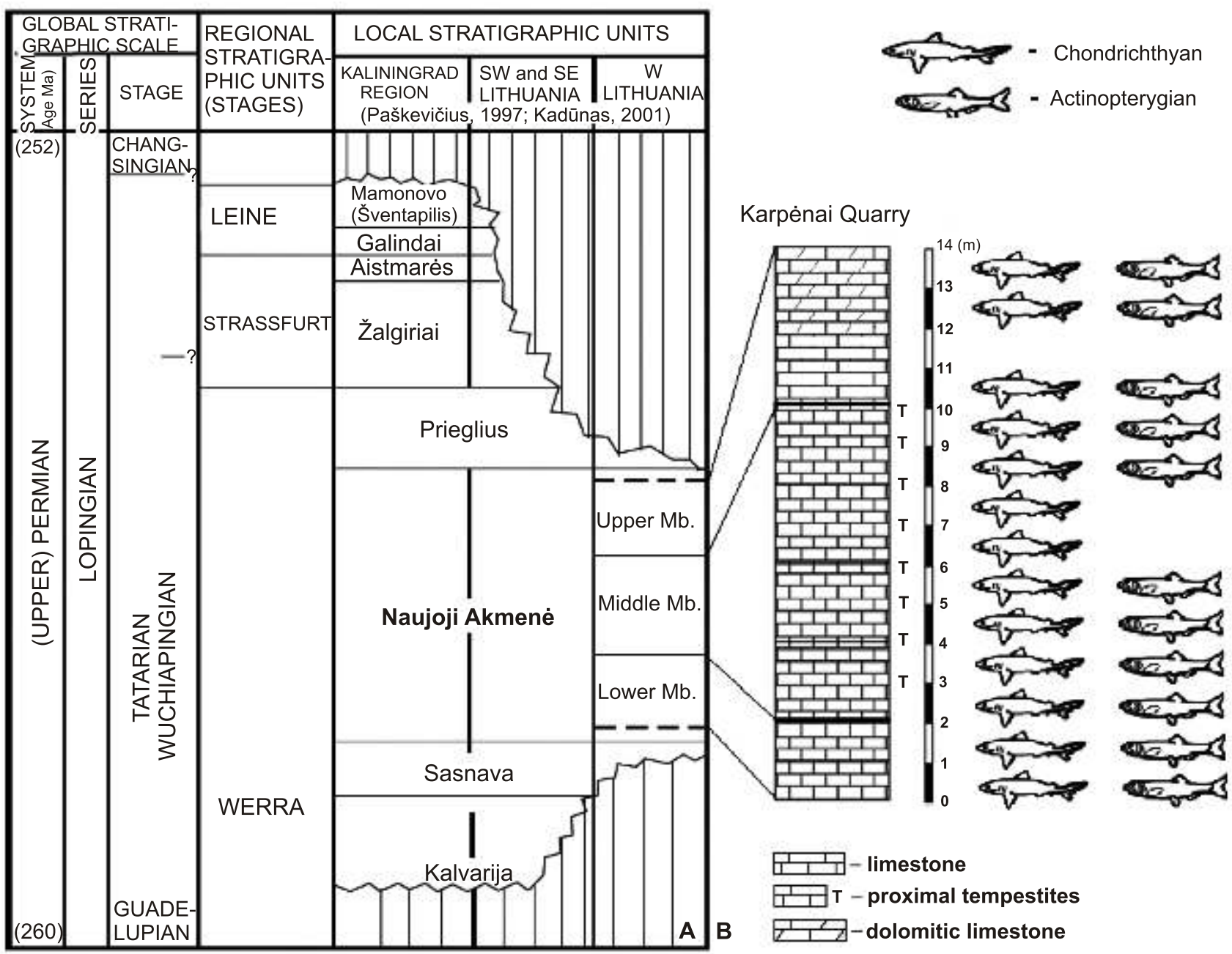

Fig. 2A - stratigraphic subdivisions of the Late Permian succession in the Lithuania and Kaliningrad region (Kadunas and Raczyński, 2010; Raczyński and Biernacka, 2014); B - finds of chondrichthyan and actinopterygian microfossils

ornamented, with irregular, radiating, and anastomosing ridges (Fig. $3 \mathrm{C}_{1}$ ). These ridges do not join in the middle of the cap tops, leaving a small area in the center (Fig. $\left.3 \mathrm{C}_{2}\right)$. The low profile and circular outline of these teeth suggest pycnodont affinities. A similar circular tooth with radiating merging ridges has been illustrated and identified as cf. Anomoeodus from the Sao Khua Formation of the Cretaceous at Phu Phan Thong in Thailand (Cavin et al., 2009: fig. 9F). Also, the teeth studied were found to have morphological similarities to Pycnodontiformes indet. from the Lower Cretaceous in Tunisia (Cuny et al., 2010: fig. 4-1a).

\section{CHONDRICHTHYAN FAUNA}

The chondrichthyans are represented by isolated remains and identified as euselachian type scales and a ?Helodus tooth (Tables 1 and 2).

The tooth studied (VU-ICH-KAR-012) (Fig. 4A) measures $2.6 \mathrm{~mm}$ mesio-distally and is $1.5 \mathrm{~mm}$ high, the root being approximately half the height of the crown (Fig. 4A 1 ). The root is perforated by numerous, randomly distributed foramina on the labial and lingual sides (Fig. $4 \mathrm{~A}_{3}$ ). It comprises a single, some- what irregular row of full and crushed different-sized canal openings below the crown. The tooth crown is devoid of ornamentation. It is oval with a smooth edge and one narrower sharp point (Fig. $4 \mathrm{~A}_{2}$ ). The tooth has been putatively assigned to the Helodontidae family. The general shape of this tooth is comparable to the Helodus-like tooth described by Eastman (1903: pl. 2, fig. 14) and to a description of a Helodus tooth in Stahl (1999). However, this tooth is also similar to that of a hybodont Lissodus sp., from the Akasaka Limestone Formation, the Middle Permian in Central Japan (Yamagishi and Fujimoto, 2011: fig. 2E, F) and to a Polyacrodus teeth from Early Permian strata in Texas (Johnson, 1981). Therefore, it is not possible to be sure that the tooth studied definitely belongs to the Helodus sp.

The 114 isolated euselachian type scales (Fig. 4B-K) belong to several morphotypes based on the crown morphology. Morphotype A (Fig. 4B, D) is represented by typical placoid scales with a flat, thick, smooth, or sometimes polygonal crown, and a high base. In most cases, the crown has a horizontal external surface and vertical lateral sides. The edges of the crown are rounded and locally undulate with tiny, short ridges. The crown and base boundary area is distinct with a well-developed and preserved neck. The base has numerous foramina of vascular canals. In places the base is higher and wider than the crown, and has an almost vertical lateral and flat basal surface. 


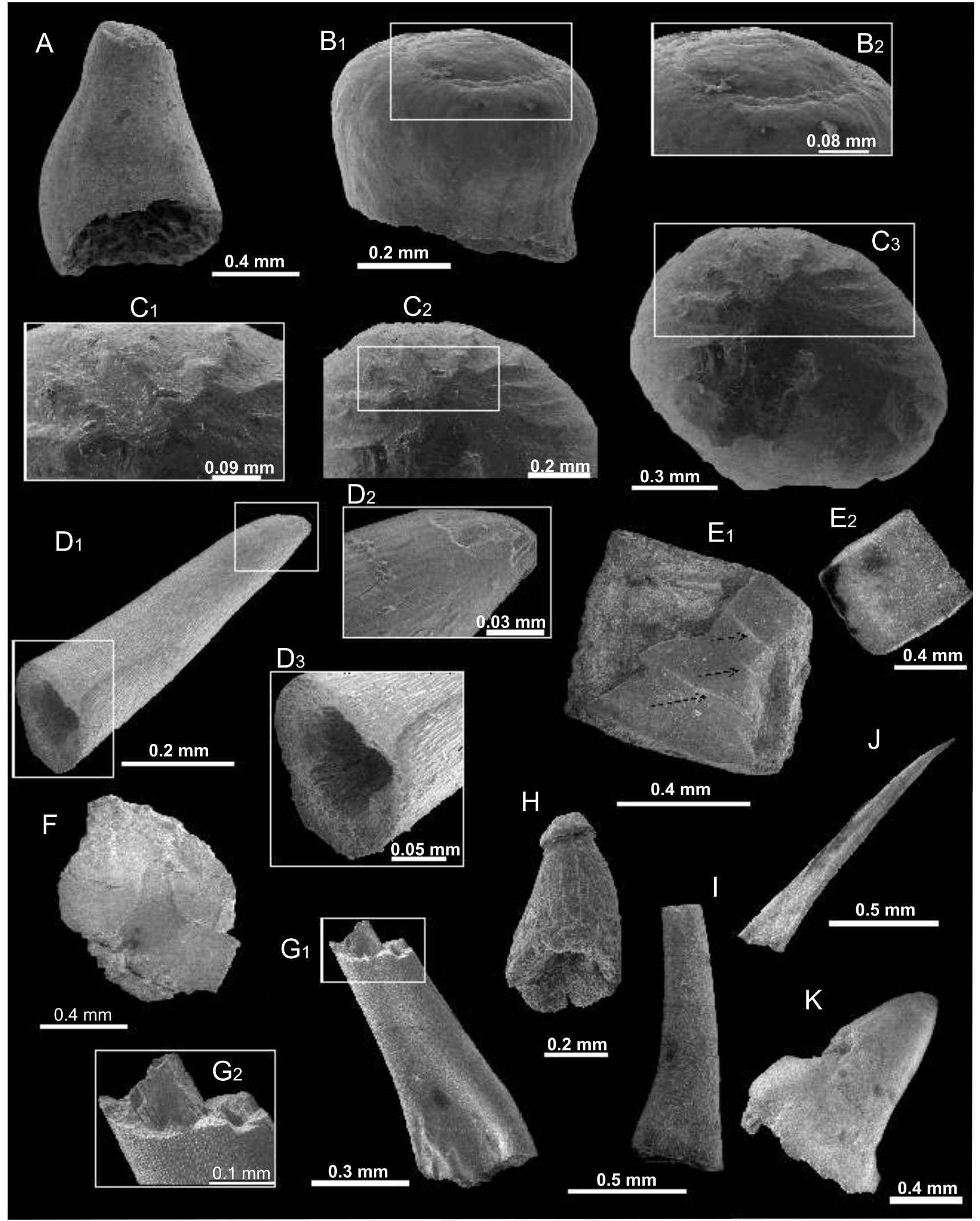

Fig. 3. Actinopterygian scales and teeth from the Naujoji Akmenė Formation, Karpènai Quarry

A - Platysomidae indet. teeth, lateral view (VU-ICH-KAR-001); $\mathbf{B}_{1}-$ Platysomidae indet. teeth, occlusal-lateral view, $\mathbf{B}_{2}-$ occlusal surface (VU-ICH-KAR-002); $\mathbf{C}_{1}-$ ?Pycnodontidae indet. teeth, with radiating ridges, $\mathbf{C}_{2}-$ a center of the cap top, $\mathbf{C}_{3}-$ apical view (VU-ICH-KAR-003); $\mathbf{D}_{1}$ - ?"Elonichthys" sp. tooth, lateral view, $\mathbf{D}_{2}$ - the distinct acrodin apex, $\mathbf{D}_{3}$ - the elongated proximo-distally microtubercles (VU-ICH-KAR-004); $\mathbf{E}_{1}$ - ?Haplolepidae indet. scale, poorly preserved outer surface, $\mathbf{E}_{2}$ - inner surface (VU-ICH-KAR-005); $\mathbf{G}_{1}-$ Palaeonisciformes indet. teeth, lateral view, $\mathrm{G}_{2}$ - narrow, vertically elongated microturbercles (VU-ICH-KAR-007) 


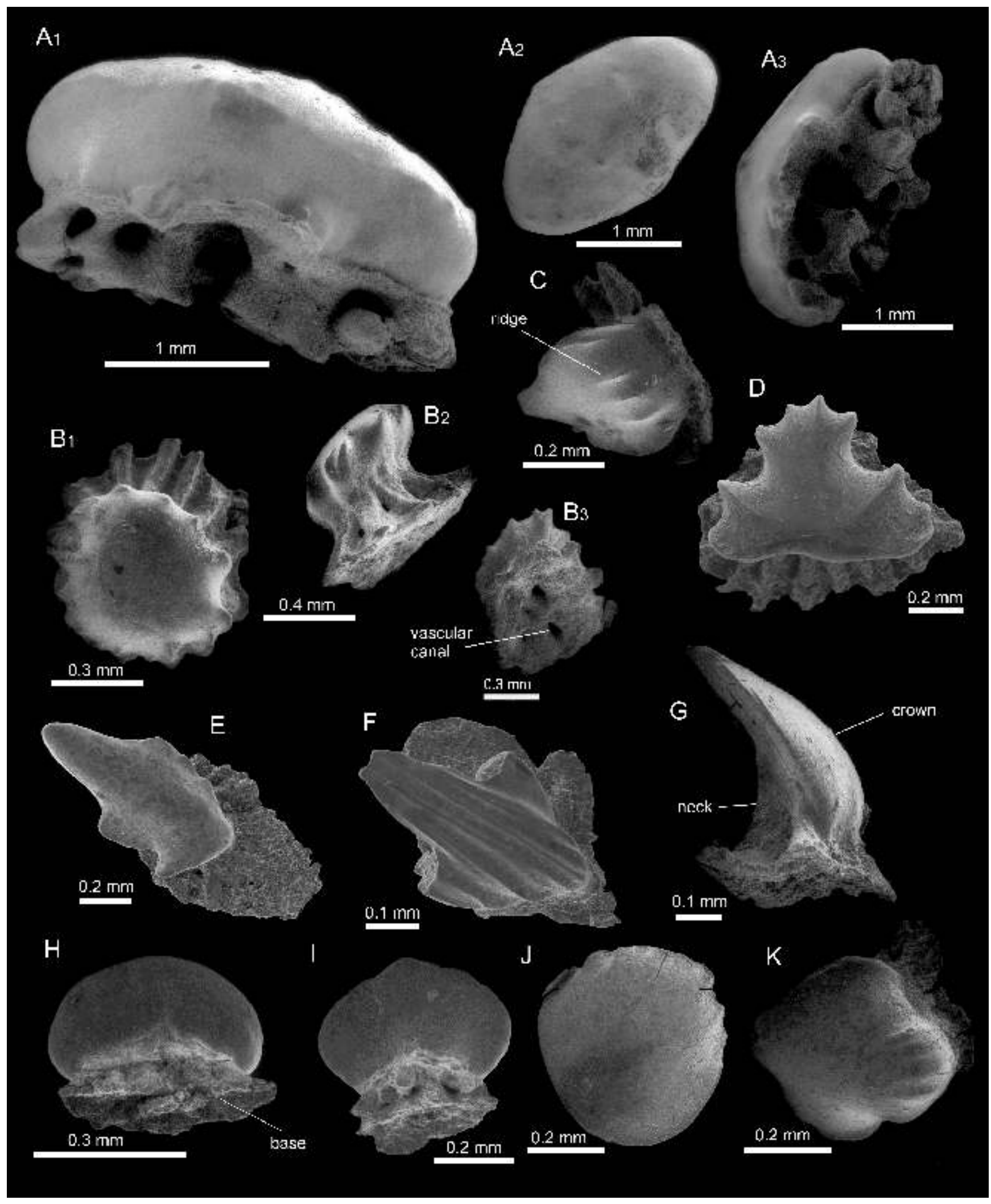

Fig. 4. Chondrichthyan scales and tooth from the Naujoji Akmenè Formation

A - ?Helodontidae indet. tooth: $A_{1}$ - lateral view, $A_{2}$ - occusal view, $A_{3}$ - lateral/basal view (VU-ICH-KAR-012); B, D - euselachian type scales of morphotype $A$ : $B_{1}$ - crown view, $B_{2}$ - anterior view, $B_{3}$ - basal view (VU-ICH-KAR-013), D - crown view (VU-ICH-KAR-014); C, E-K - euselachian type scales of morphotype B: C - anterior view (VU-ICH-KAR-015), E - crown view (VU-ICH-KAR-016), F - crown view (VU-ICH-KAR-017), G - lateral view (VU-ICH-KAR-018), H - postero-basal view (VU-ICH-KAR-019), I - postero-basal view, (VU-ICHKAR-020), J - crown view (VU-ICH-KAR-021), K - crown view (VU-ICH-KAR-022) 
The roundish scales range in diameter to $0.6 \mathrm{~mm}$ (Fig. 4B), while the polygonal crown is $1.0 \mathrm{~mm}$ in width and $0.8 \mathrm{~mm}$ in length (Fig. 4D). The morphotype B scales (Fig. 4C, E-K) have a drop-like, elongated, or rarely oval crown (Fig. 4J), a well-developed neck, which is smaller, or sometimes bigger, than the crown base. The crown is strongly inclined and the pointed posterior edge overtops beneath the blunt anterior part. The slightly convex external surface of the crown is smooth (Fig. 4E, G), or in places has distinct medial ridges. The medial ridge varies from being short, reaching anterior edge (Fig. 4C, K) to being wide and long, reaching the posterior edge (Fig. 4F). The scale neck is narrow, or in some instances wide (Fig. 4H), low in the anterior part and high posteriorly. The base has a concave (Fig. $4 \mathrm{I})$ or flat basal surface. The crowns of scales are small, from $0.2-0.8 \mathrm{~mm}$ in length, and $0.4 \mathrm{~mm}$ in width. A polygonal crown similar to that from morphotype A (Fig. 4D) has been described by Reif (1978: fig. 9C) from the Lower Muschelkalk, the Middle Triassic in Central Germany, and assigned to the Hybodontidae family. Although, the anterior part of the Hybodus scale, as presented by Reif (1978), has a distinct constriction. However, the hybodontids have scales very similar to the placoid scales of the euselachians (Reif, 1978). Moreover, the similar crown with undulating ridges (Fig. 4B) was named a Jannasa korni placoid scale (Brandt, 1996) from the Zechstein Limestone of Germany. Scales similar to morphotype B scales have been illustrated and described from the Middle Permian in West Texas, USA as euselachian scales by Ivanov et al. (2013: fig. 5A, B). Manzanares et al. (2014: fig. 1a) named similar drop-like scales from the Middle Triassic in Spain as Glabrisubcorona-type hybodontiform scale based on their histology. Many scales similar to morphotype $A$ and morphotype $B$ based on their crown morphology were found in Middle and Late Triassic strata in British Columbia, Canada and described as elasmobranch scales (Johns, 1996).

\section{DISCUSSION}

The vertebrate assemblage from the Naujoji Akmenè Formation in Karpènai Quarry comprises actinopterygian and chondrichthyan material of low abundance and Late Permian age. The actinopterygian remains are represented by teeth and scales from mostly palaeonisciforms and pycnodontiforms, while the chondrichthyans are represented by various euselachian-type scales and a ? Helodus sp. tooth.

The Late Permian palaeoniscoids were widely distributed geographically and occurred in many environments. For example, representatives of this taxon occur in localities ranging from Australia and South Africa (Campbell and Phuoc, 1983; Bender, 1999, 2001, 2006); to European Russia (Minikh, 1990; Esin, 1995). Whole Platysomidae skeletons and some isolated fragments have been found in the Upper Kazanian Stage, the Middle Permian, and Upper Permian of the East European Platform of Russia (Solodukho, 1951; Esin, 1993); well-preserved Platysomus sp. and Palaeoniscum sp. skeletons have been found in the Lopingian Stage, the Upper Permian in northwest Germany (Diedrich, 2009). Elonichthys sp. skeletons and skull fragments came from Permo-Carboniferous lakes strata in the Czech Republic and in the Saar-Nahe Basin in south-west Germany (Schindler, 1993; Zajíc, 2004, 2007; Štamberg, 2014); some Elonichthys sp. microremains have been found in Permian deposits in Norway (Heintz, 1934). Haplolepis sp. remains are known from the Middle Permian of West Texas, USA (Ivanov et al., 2015).
Four main orders of chondrichthyans: Hybodontiformes, Xenacanthiformes, Symmoriiformes, and Ctenacanthiformes are represented in Middle and Late Permian basins in Eastern Europe (Minikh and Minikh, 2009). Moreover, euselachian scales are known from the Kazanian Stage, Middle Permian, of Russia (Ivanov and Lebedev, 2014). Also, Helodus sp. fragments have been found in Permian deposits of West Australia (Teichert, 1943).

A more detailed taxonomic analysis of the fish fauna in the Karpenai Quarry needs additional and well-preserved material, allowing microstructural and histological investigation. That might then help Upper Permian stratigraphic correlation in the Polish-Lithuanian part of the Zechstein Basin.

The rarity of these fish microremains can be explained in several ways. The Zechstein Basin had some similarities with the palaeoenvironmental situation in the Miocene Mediterranean Sea during the Late Miocene Salinity Crisis. The Mediterranean Sea was at least partially isolated from the Atlantic Ocean, and flow of less saline water from the ocean was restricted. As a result, the eastern part of the basin was hypersaline and highly restricted (Blanc, 2006). The same effects may have affected to some extent the Lithuanian part of the basin, from its distal location from the Arctic Boreal Ocean during the Late Permian (Sørensen et al., 2007). Increased salinity may be one potential limiting factor for the distribution of fish. Also, the disappearance of the thermocline in coastal areas of upwelling may cause extreme marine fertility and anoxia promoting the development of bituminous sediments (Brongersma-Sanders, 1971). The limestone and dolostone samples studied were enriched with bitumen, especially, in the middle member in Karpenai Quarry. High phytoplankton productivity may have caused eutrophication, to result in the depletion of dissolved oxygen in the water.

Moreover, Lithuania's coastal zone was much wider than those of the southern parts of the basin (e.g., in SW Poland) as a result of prolonged erosion of the platform, and low topographic relief across a large territory (Raczyński and Biernacka, 2014). This possibly reduced circulation, which could have resulted in restricted high-temperature and low-oxygen conditions, which also did not favour conditions for vertebrates. All these factors may have contributed to the low diversity and abundance of the fossil fish in the area studied.

\section{CONCLUSIONS}

Study of the Karpenai Quarry sections yielded chondrichthyan and actinopterygian assemblages, usually extremely rare in the Upper Permian of northern Lithuania. Large samples of tens to hundreds of kilogram of rock are needed to yield sufficient sample sizes to reveal the diversity of the microvertebrate remains

The poor taxonomic diversity of fish fauna in the Karpènai locality may be explained by the former presence of restricted, high-salinity environments, due to the generally flat coastal zone of the northeastern shore of the Zechstein Sea, and the very distal location from the Boreal Ocean.

Acknowledgements. We would like to express our cordial thanks to A. Ivanov (St. Petersburg State University, Russia), and V. Karajūtè-Talimaa (Vilnius University, Lithuania), who helped with the identification of our material. Many thanks to A. Ivanov for his useful papers on the Permian ichthyofauna and to P. Raczyński (University of Wroclaw, Poland), for his helpful reviews on the stratigraphy of the area studied, and to 
L. Šiliauskas (Nature Research Center, Lithuania) and E. Manzanares (University of Valencia, Spain) for taking SEM micrographs. We would also like to thank $A$. Ivanov and $M$. Ginter (University of Warsaw, Poland) for their many crucial remarks which significantly improved the article. This research was carried out by the Open Access to the research infrastructure of the Nature Research Centre (Vilnius) under the Lithuanian open access network initiative.

\section{REFERENCES}

Argyriou, T., Romano, C., Carrillo-Briceño, J.D., Brosse, M., Hofmann, R., 2017. The oldest record of gnathostome fossils from Greece: Chondrichthyes from the Lopingian of Hydra Island. Palaeontologia Electronica, 20: 1-9.

Bender, P.A., 1999. First documentation of similar Late Permian actinopterygian fish from Australia and South Africa. Records of the Western Australian Museum, 57: 183-189.

Bender, P., 2001. A new actinopterygian fish species from the Late Permian Beaufort Group, South Africa. Palaeontologia Africana, 37: 25-40.

Bender, P., 2006. A new deep-bodied Late Permian actinopterygian fish from the Beaufort Group, South Africa. Palaeontologia Africana, 41: 7-22.

Biernacka, J., Borysiuk, K., Raczyński, P., 2005. Zechstein (Ca1) limestone-marl alternations from the North-Sudetic Basin, Poland: depositional or diagenetic rhythms? Geological Quarterly, 49 (1): 1-14.

Blanc, P.L., 2006. Improved modelling of the Messinian Salinity Crisis and conceptual implications. Palaeogeography, Palaeoclimatology, Palaeoecology, 238: 349-372.

Brandt, S., 1996. Janassa korni (Weigelt) - Neubeschreibung eines petalodonten Elasmobranchiers aus dem Kupferschiefer und Zechsteinkalk (Perm) von Eisleben (Sachsen-Anhalt). Paläontologische Zeitschrift, 70: 505-520.

Brongersma-Sanders, M., 1971. Origin of major cyclicity of evaporites and bituminous rocks: an actualistic model. Marine Geology, 11: 123-144.

Campbell, K.S.W., Phuoc, L.D., 1983. A Late Permian actinopterygian fish from Australia. Palaeontology, 26: 33-70.

Cavin, L., Deesri, U., Suteethorn, V., 2009. The Jurassic and Cretaceous bony fish record (Actinopterygii, Dipnoi) from Thailand. Geological Society Special Publications, 315: 125-139.

Clapham, M.E., Bottjer, D.J., 2007. Permian marine paleoecology and its implications for large-scale decoupling of brachiopod and bivalve abundance and diversity during the Lopingian (Late Permian). Palaeogeography, Palaeoclimatology, Palaeoecology, 249: 283-301.

Cuny, G., Cobbett, A.M., Meunier, F.J., Benton, M.J., 2010. Vertebrate microremains from the Early Cretaceous of southern Tunisia. Geobios, 43: 615-628.

Diedrich, C.G., 2009. A coelacanthid-rich site at Hasbergen (NW Germany): taphonomy and palaeoenvironment of a first systematic excavation in the Kupferschiefer (Upper Permian, Lopingian). Palaeobiodiversity and Palaeoenvironments, 89: 67-94.

Eastman, C.R., 1903. Carboniferous fishes from the Central Western States. Bulletin of the Museum of Comparative Zoology, 39: 161-226.

Esin, D.N., 1990. The scale cover of Amblypterina costata (Eichwald) and the palaeoniscid taxonomy based on isolated scales (in Russian). Paleontological Journal, 2: 90-98.

Esin, D.N., 1993. New species of deep-bodied actinopterygians (Platysomidae) from the Upper Permian of the East European Platform (in Russian). Paleontological Journal, 3: 166-171.

Esin, D.N., 1995. Ontogenetic development of the squamation in some palaeoniscoid fishes. Bulletin du Muséum National d'Histoire Naturelle, 17: 227-234.
Gasiūnienè, V.E., Kadūnas, V., 1997. Lietuvos viršutinio permo klinties pramoninè charakteristika (in Lithuanian). Geologija, 22: 50-55.

Gailius, R., Grigelis, A., Jankauskas, T., Juodkazis, V., Juozapavičius, G., Kadūnas, V., Katinas, V., Klimas, A., Kondratas, A., Kondratienè, O., Linčius, A., Mikalauskas, V., Narbutas, V., Paškevičius, J., Sakalauskas, K., Suveizdis, P., Tarvydas, R., Vonsavičius, V., 1994. Lietuvos geologija (in Lithuanian). Mokslo ir Enciklopediju Leidykla, Vilnius.

Hampe, O., Hairapetian, V., Dorka, M., Witzmann, F., Akbari, A.M., Korn, D., 2012. A first late Permian fish fauna from Baghuk Mountain (Neo-Tethyan shelf, central Iran). Bulletin of Geosciences, 88: 1-20.

Heintz, A., 1934. Fischreste aus dem Unterperm Norwegens. Norsk Geologisk Tidsskrift, 14: 176-194.

Ivanov, A.O., Nestell, G.P., Nestell, M.K., 2013. Fish assemblage from the Capitanian (Middle Permian) of the Apache Mountains, West Texas, USA. New Mexico Museum of Natural History and Science, Bulletin, 60: 152-160.

Ivanov, A.O., Lebedev, O.A., 2014. Permian chondrichthyans of the Kanin Peninsula, Russia. Paleontological Journal, 48: 1030-1043.

Ivanov, A.O., Nestell, M.K., Nestell, G.P., 2015. Middle Permian fish microremains from the Early Capitanian of the Guadalupe Mountains, West Texas, USA. Micropaleontology, 61: 301-312.

Jeppsson, L., Anehus, R., Fredholm, D., 1999. The optimal acetate buffered acetic acid technique for extracting phosphatic fossils. Journa of Paleontology, 73: 964-972.

Johns, M.J., 1996. Diagnostic pedicle features of Middle and Late Triassic elasmobranch scales from northeastern British Columbia, Canada. Micropaleontology, 42: 335-350.

Johnson, G.D., 1981. Hybodontoidei (Chondrichthyes) from the Wichita-Albany Group (Early Permian) of Texas. Journal of Vertebrate Paleontology, 1: 1-41.

Johnson, G.D., Zidek, J., 1981. Late Paleozoic phyllodont tooth plates. Journal of Paleontology, 55: 524-536.

Kadūnas, V., 1997. Sedimentaciniu procesu itaka viršutinio permo klinties klodo storiui ir mineralinei sudèčiai Šiaurès Lietuvoje (in Lithuanian). Geologija, 22: 36-42.

Kadūnas, V., 2001. Lietuvos permo halogeninè formacija: litologija, geochemija, naudingosios iškasenos (in Lithuanian). Geologijos institutas, Vilnius.

Kadunas, V., Raczyński, P., 2010. Lithuania and Latvia - the easternmost part of the Southern Permian Basin. In: Petroleum Geological Atlas of the Southern Permian Basin Area (eds. J.C. Doornenbal and A.G. Stevenson): 141-142. EAGE Publications b.v. (Houten).

Kličius, J., 2006. Akmenès rajono Karpèny klinties telkinio naujo ploto detalios žvalgybos ataskaita (in Lithuanian). Gelmiu Tyrimai, Vilnius.

Kličius, J., Čiūraitè, K., 2010. Akmenès rajono Karpèny klinties telkinio naujo ploto detalios žvalgybos ataskaita (in Lithuanian). Gelmiu Tyrimai, Vilnius.

Kozur, H., 1995. Permian conodont zonation and its importance for the Permian stratigraphic standard scale. Geologisch-Paläontologische Mitteilungen Innsbruck, 20: 165-205. 
Manzanares, E., Plá, C., Martínez-Pérez, C., Rasskin, D., Botella, H., 2014. The enameloid microstructure of euselachian (Chondrichthyes) scales. Paleontological Journal, 48: 1060-1066.

Minikh, A.V., 1990. Novyi paleonisk iz pozdney permi vostochno-evropeyskoy platformy (in Russian). Paleontologicheskiy Zhurnal, 3: 71-76

Minikh, A.V., Minikh, M.G., 2009. Osnovnye sobytiya v razviti sredne i pozdnepermskoy ikhtiofauny Vostochnoy Evropy (in Russian). Nauchnaya Kniga, 141-157.

Paškevičius, J., 1997. The Geology of the Baltic Republics. Vilnius University, Geological Survey of Lithuania, Vilnius.

Peryt, T.M., Geluk, M.C., Mathiesen, A., Paul, J., Smith, K., 2010. Zechstein. In: Petroleum Geological Atlas of the Southern Permian Basin Area (eds. J.C. Doornenbal and A.G. Stevenson): 123-147. EAGE Publications b.v. (Houten).

Peryt, T.M., Durakiewicz, T., Kotarba, M.J., Oszczepalski, S. Peryt, D., 2012. Carbon isotope stratigraphy of the basal Zechstein (Lopingian) strata in Northern Poland. Geological Quarterly, 56 (2): 285-298.

Raczyński, P., Biernacka, J., 2014. Zechstein in Lithuania-Latvia border region. Geologija, 2: 57-62.

Reif, W.E., 1978. Types of morphogenesis of the dermal skeleton in fossil sharks. Paläontologische Zeitschrift, 5: 110-128.

Schindler, T., 1993. "Elonichthys" palatines n. sp., a new species of actinopterygians from the Lower Permian of the Saar-Nahe Basin (SW-Germany). New Research on Permo-Carboniferous Faunas. Pollichia-Buch, 29: 67-81.

Solodukho, M.G., 1951. Nakhodki predstaviteley sem. Platysomidae $\mathrm{v}$ verkhnekazanskikh otlozheniyakh okrestnostey $\mathrm{d}$ Pechishchi (Tatarskaya ASSR) (in Russian). Uchyonnye Zapisi kazanskogo Gosudarstvennogo Universiteta im. V.I. Ul'yanova-Lenina, 111: 157-159.

Sørensen, A.M., HDkansson, E., Stemmerik, L., 2007. Faunal migration into the Late Permian Zechstein Basin - evidence from bryozoan palaeobiogeography. Palaeogeography, Palaeoclimatology, Palaeoecology, 251: 198-209.

Stahl, B.J., 1999. Chondrichthyes III. Holocephali. In: Handbook of Paleoichthyology (ed. H.P. Schultze). Friedrich Pfeil, München.
Suveizdis, P., 1962. Stratigrafiya permskikh otlozheniy Polsko-Litovskoy sineklizy po novym paleontologicheskim materialam (in Rrussian). Moksliniai Pranešimai: Geologija Geografija, 14: 5-32.

Suveizdis, P., 1963. Verkhnepermskie otlozheniya Polsko-Litovskoj sineklizy (in Russian). Voprosy Geologii Litvy, Vilnius.

Suveizdis, P. (ed.), 1975. Permian deposits of the Baltic region (stratigraphy and fauna) (in Russian with English summary). Lietuvos Geologijos Mokslinio Tyrimo Institutas, Trudy, Vilnius.

Štamberg, S., 2014. Discovery of skeletal fragments of a large amphibian and other Permian fauna from locality Arnultovice in the Krkonoše Piedmont Basin (in Czech). Geoscience Research Reports, 47: 94-97.

Štamberg, S., 2016. Actinopterygians of the Stephanian sediments of the Krkonoše Piedmont Basin (Bohemian Massif) and their palaeobiogeographic relationship. Bulletin of Geosciences, 91: 169-186.

Teichert, C., 1943. Bradyodont sharks in the Permian of Western Australia. American Journal of Science, 243: 543-552.

Trinajstic, K., 1977. Scale morphology of the Late Devonian palaeoniscoid Moythomasia durgaringa Gardiner and Bartram 1977. Alcheringa, 23: 9-19.

Wang, N.Z., Zhang, X., Zhu, M., Zhao, W.J., 2009. A new articulated hybodontoid from Late Permian of northwestern China. Acta Zoologica, 90: 159-170.

Westoll, T.S., 1944. The Haplolepidae, a new family of Late Carboniferous bony fishes. Bulletin of the American Museum of Natural History, 83: 1-122.

Yamagishi, H., Fujimoto, T., 2011. Chondrichthyan remains from the Akasaka Limestone Formation (Middle Permian) of Gifu Prefecture, Central Japan. Bulletin of the Kanagawa Prefectural Museum, Natural Science, 40: 1-6.

Zajíc, J., 2004. Vertebrate biozonation of the Permo-Carboniferous lakes of the Czech Republic - new data. Acta Musei Reginaehradecensis S.A., 30: 15-16.

Zajíc, J., 2007. Carboniferous Fauna of the Krkonoše Piedmont Basin. Acta Musei Reginaehradecensis S.A., 32: 11-16. 